\title{
ingenta
}

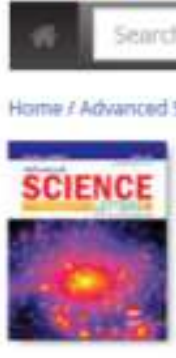

earch ingenta Conned

Search by

e.

Aavanged

Publication in Publisher subject:

Horne if Advarnced Soence i stren, Volume 23, Number T

\section{Frame Effects on Outdoor- Indoor Transmission Class of Fixed and Open Glass Windows}

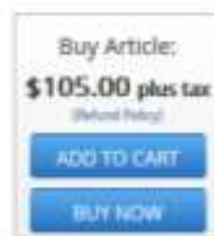

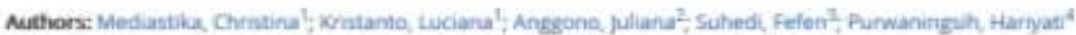
Source: Advanced Science Letterx Volume 23, Number 7, Juby 2017, pp. 6168-61720:

Publisher: American Scientific: Publishers

Dot fittips/idolorghe.1166/ast 20179229

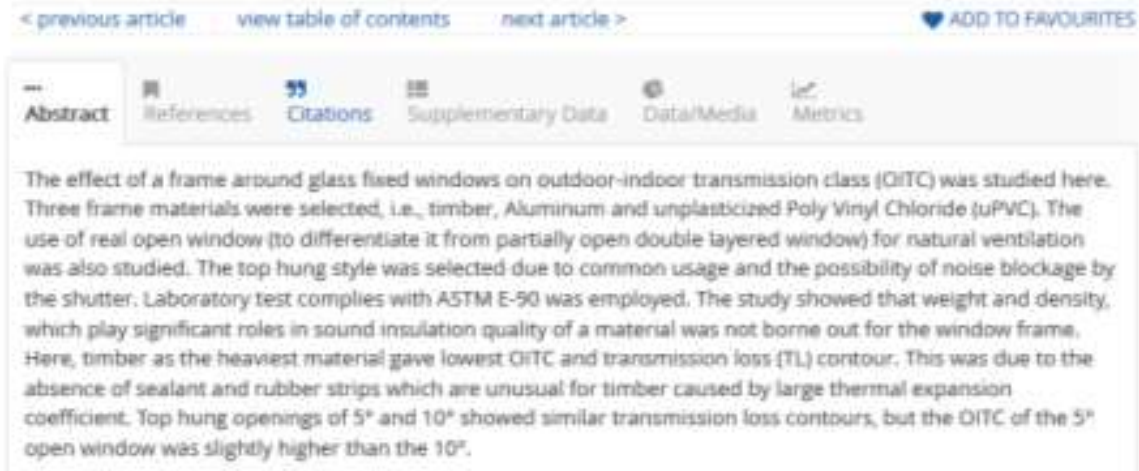

Keywords: Frame; Orre, Open Window, Theo Fued Window, Traramission Loss

Document Type: Research Arocie

Antiations: 1: Department of Architecture Fetra Christian Univessicy, 5urabaya 502a6, indonesia 2 Department of Mechanical Fngineering Fetra Christian Unversity, Surabaya 60235, indonevia $\mathbf{x}$ : Research and Development Center for Housing and Settlement, Ministry of Public Works and Housing, Bandung 40622 , indonesia 4 :Degartment of Material Engineering, Institut Teknologi Sepuluh Nopember, Siarabaya 60111, Indonesia

Aublcation date: july 1, 2017

> More about thes putalication?

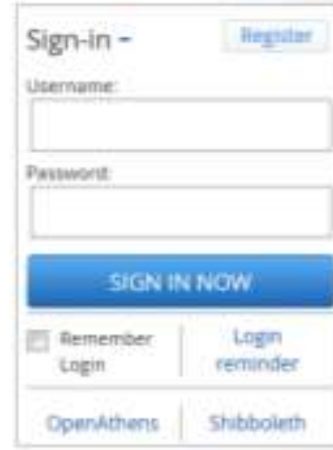

Tools

C Heferwics exports-

8. Linkinit aptions +

[D] Barcelve new issiar aiert

in Latest TOC RSS Feed

A flecent issues ass feed

Q Ger Permissions

Q Favourite:

Plth Bahasa

Coersaywam weh Go git Teriemahan

Share Content

F 9 in mon 


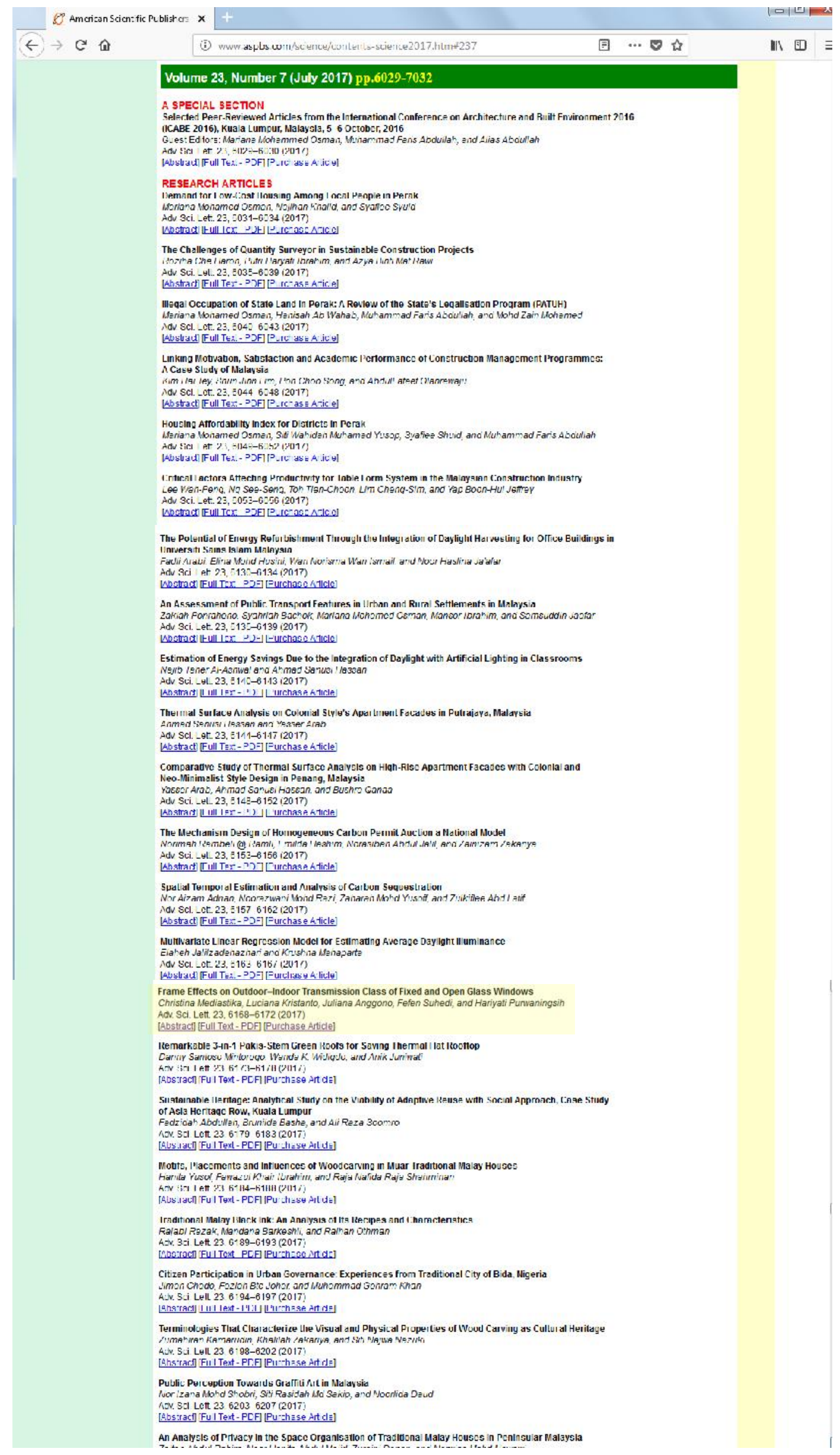




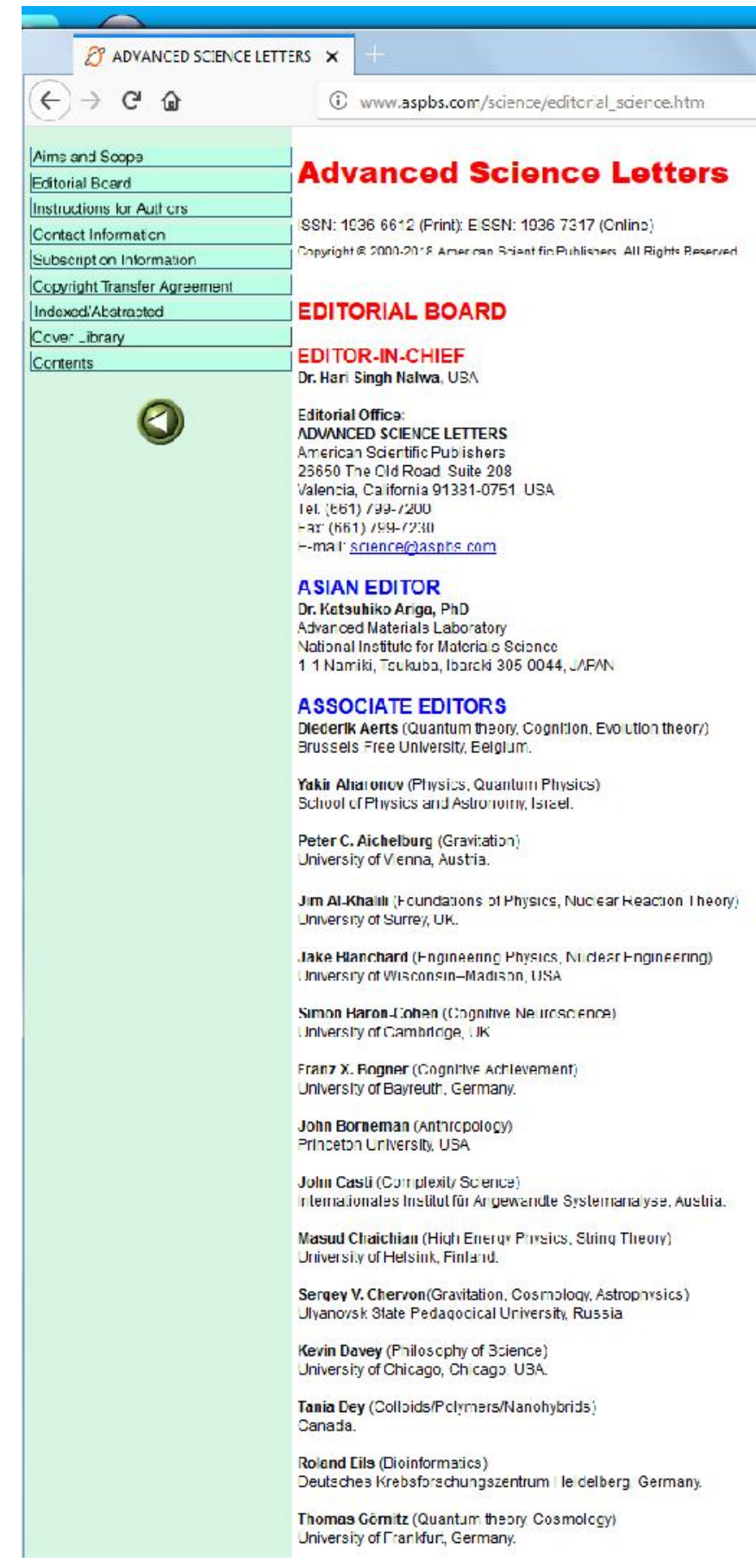

Aims and Soop

Instructions lur Ault crs

SSN: $103666-2$ (Frint): ESSN: 19367317 (Cnlin))

EDITORIAL BOARD

exodiatstrastod

EDITOR-IN-CHIEF

Editorial Offic:

ATUNCED SCIENCELETTERS

alenzia, Ca ifornia 91331-0751 USA

el. 661$) / 9 y-1200$

. Katsuhiko Ariga, PhD

Atvar œed Materials Labo'atory

1 Nariki TcL ho

ASSOCIATE EDITOR

Brussels =ree Universit/, Eelol.un.

Peter C. Aichelburg (Graviation)

Jm Al-Khaill itcunctajons 3 thysics, Nuc ear Heacion I heory

Iniversty at wisconsin-Madison, Us

Inlversly of Cambringe, It

Jolun Caslis (Cjun ulexil/ Sc ence)

Nasud Chaichian (Hiuhı Enerur P resics, Strinu Theory)

i.y ur Helsink, Finlstis.

Davey (Philoscphy of Science)

Roiend Lils (Dioinformatics)

Thomas Gormitz (Quantım the ryy Cosmolcogy)

Jniversiy of $\Gamma$ rar Ifur, German 


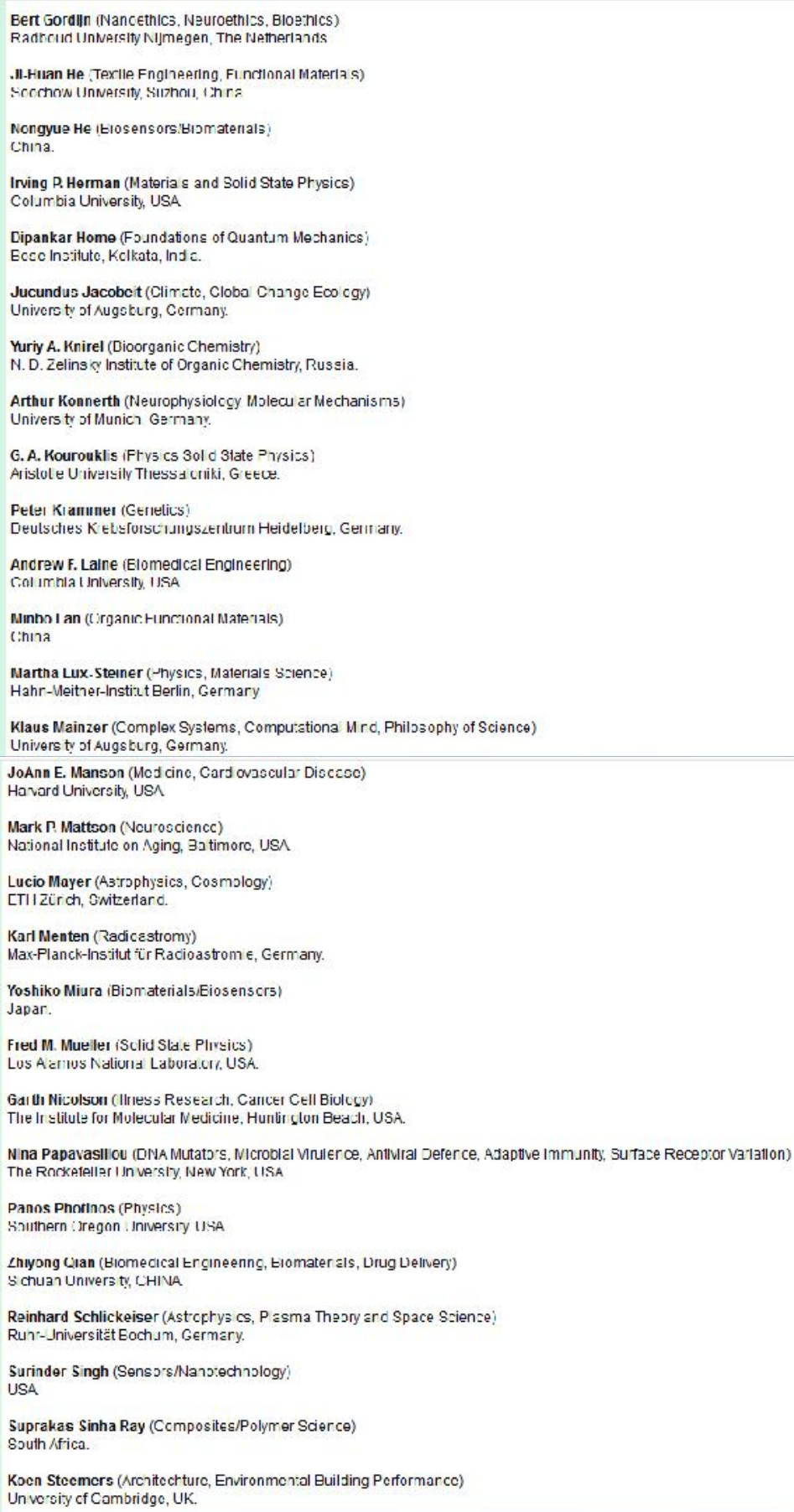


Shinsuke Tanabe (Environmental Cheristry ard Ecctoxicolocy)

Erime University Jaran.

James $R$. Thompson (Sold State วpvslcs)

The Univer sily or Te' IIIesseet. USA

Uwe Ulbrich (Clin at, Meteor ogy)

Гreie Universitz̈t Derl n, Germany.

Ahmad Umar (Advanzad Materia

Najran University, Saudi Arabia.

Frans de Waal (Anımal Hehaviar and (:conit on

Emory UriversIy, USA.

EDITORIAL BOARD

Fil ppo Aurgli, Liverpocl John Morres University, UK

Marcel Ausloos, Université de _lègg, Belgium

Martin Hojowald Pennscyvania State I Iriversity US

Sougato Bose, Lriversly Ccllege. Lcndon UK

Jacopo Buonglorno, NIT, LSA.

Paul Cul unatis, Univers ti of Pelras Gieecy

Maria Luisa Dalla Chiara, Univers ty of Firenze, Italy

Dionysios Demetriou Dionysiou, University of Cincinnati, JSA

Simon Eidelman, Budker Ir ctitute of Nuclear Prysics Rusei

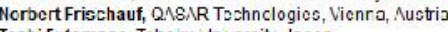

Toshi Futamase, Toho ku Unversity, Japan

Leono Gavriov, Jnive sity o Cnicago, USA

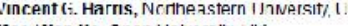

Mae-Wan Ho, Oren Unlyersits. JK

Keillt Hulchisson, Unirets sily of Melboune, Austr alid

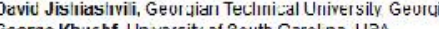

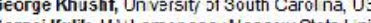

Forschunçezentum Karlsruhe Cormany

Alexander Lebedev, _aboratory of Semizond der $\mathrm{Dev}$ ces Physizs, Russia

James Lindesay, -lo'Na.O University USA

Michael Lipkind, Kimron Yeterinary nstitute, Israel

Nigel Mason, : Jpen I Inversity IJK

Johnjoe MacFadden. Univers ty of SLrrey. UK

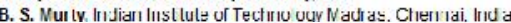

lleiko Paeth, Geocraphisches Institt der Lnivers tāt Würzb Jrg German

Matteo Paris, Universita' di Milano, Itali

Davd Fosoda, Jniversiy o "Nac, Soain

Peddy II. Regan, Unversity of Gurrey, UK

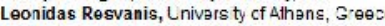

IVoligang Knoce, University Jt Lcrotrund. Germar

Derek C. Richard son, Lnivers ty of Maryland, U3A

Carlos Romero, Universidade Federal da Paraita, Braz

Andrea Sella, I Iniversity C:allege I andาn, I oncon, Uk

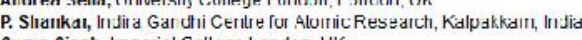

Surya Singh, Impcrial Colle çe London, UK

I ennidas Sotirnpoulos, I Iriversity of Paras, Greere

Rueue Su and. Universily or Eercerı Norway

Kerl Svozil, Technische Lnivers tät Wier, Aucstr

Kit Tan, Orive'sit/ of Copenhajen, Denmark

Roland Tav. Centre de Fh/saue Theor que, CNFS, Marsellle, France

Remi Vainio, University of l lelsinki, $\Gamma$ nlan

ratory of Theoretizal Phvsics Dubna, Russia

University Hellas:. Northern ireland

Lijian Xu, Hunan Unversity of Technolocy, Chir a

Wus

Auraam 7elilidis, Iniversity of Patras, Freecse

Alexander V. Zolulai yuk, Lk air iar Acadentry cr Sciences, Ukjeine

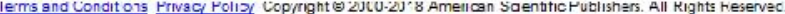




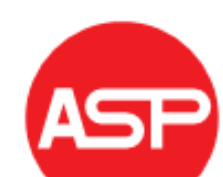

Copyright (C) 2017 American Scientific Publishers

All rights reserved

Printed in the United States of America
Advanced Science Letters

Vol.27, Number 7, 2017

AMERICAN

SCIENTIFIC

PUBLISHERS

\title{
Frame effects on OITC of fixed and open glass windows
}

\author{
Christina Mediastika*1, Luciana Kristanto ${ }^{1}$, Juliana Anggono ${ }^{2}$, Fefen Suhedi ${ }^{3}$, Hariyati Purwaningsih ${ }^{4}$ \\ ${ }^{1}$ Department of Architecture Petra Christian University, Surabaya 60236, Indonesia \\ ${ }^{2}$ Department of Mechanical Engineering Petra Christian University, Surabaya 60236, Indonesia \\ ${ }^{3}$ Research and Development Center for Housing and Settlement, Ministry of Public Works and Housing, Bandung 40622 Indonesia \\ ${ }^{4}$ Department of Material Engineering, Institut Teknologi Sepuluh Nopember, Surabaya 60111 Indonesia
}

\begin{abstract}
The effect of a frame around glass fixed windows on outdoor-indoor transmission class (OITC) was studied here. Three frame materials were selected, i.e. timber, Aluminum and unplasticized Poly Vinyl Chloride (uPVC). The use of real open window (to differentiate it from partially open double layered window) for natural ventilation was also studied. The top hung style was selected due to common usage and the possibility of noise blockage by the shutter. Laboratory test complies with ASTM E-90 was employed. The study showed that weight and density, which play significant roles in sound insulation quality of a material was not borne out for the window frame. Here, timber as the heaviest material gave lowest OITC and transmission loss (TL) contour. This was due to the absence of sealant and rubber strips which are unusual for timber caused by large thermal expansion coefficient. Top hung openings of $5^{\circ}$ and $10^{\circ}$ showed similar transmission loss contours, but the OITC of the $5^{\circ}$ open window was slightly higher than the $10^{\circ}$.
\end{abstract}

Keywords: Fixed Window, Open Window, Frame, Transmission Loss, OITC.

\section{INTRODUCTION}

Buildings reside in the tropics experience excessive solar radiation throughout the years. Here, the use of lightweight materials and openings to maintain the indoor comfort of naturally ventilated buildings is common. Even for air conditioned buildings, the needs to sometimes open the windows for fresh air is not avoidable. With the increase of environmental noise, traffic noise, in particular, the use of a 'real' open window for natural ventilation is impractical. The term of a real open window is applied here to separate it from a partially open double layered window.

When compared to heavy and high-density materials, the use of lightweight or breathable materials reduces sound insulation quality ${ }^{1-3}$. Sound transmission class (STC) and outdoor-indoor transmission class (OITC) of thin and transparent materials are lower than thick *Email Address: eviutami@ petra.ac.id and opaque materials ${ }^{4-6}$. The use of a real open window allows noise intrusion into living spaces even worse. However, since an open window is common and significant for natural ventilation, information on the sound insulation quality of a real open window is important for users to consider a better application.

Here the term of a real open window is applied since there were studies of sound insulation of non-real open windows $^{7-9}$. Buratti ${ }^{7,8}$ focused more on the use of various ceilings to support the work of an open window. Ford and Kerry ${ }^{9}$ studied a partially open double glazing window which is inadequate for naturally ventilated building in the tropics ${ }^{10}$.

Besides the critical issue of noise transmission by an open window, usage of various material for window frame was also raised. Typical frame materials in Indonesia are timber and later, Aluminum (Al). A good quality timber such as teak (Tectona grandis) is preferred, but this is not widely utilized due to its price. Today, 
rather than using low-quality timber, Indonesians tend to use Aluminum for window and door frames. The aluminum frame is also available in various brands and quality. After the trend of Aluminum frame, recently, some buildings in Indonesia begin to use unplasticized Poly Vinyl Chloride (uPVC) frame. It was triggered by a promotion uPVC gives more benefits than the earlier frame materials. The high price is still an obstacle in using a uPVC frame. When using Aluminum or uPVC, sealant and rubber strips are applied, but not in the case of timber. The absence of sealant on timber is due to high coefficient thermal expansion ${ }^{11}$. For frame made from good quality wood such as teak which the thermal expansion coefficient is lower than low-quality wood, the sealant may be applied, but it remains unusual.

\section{METHODS}

Examinations of fixed glass windows with three frame materials and open windows with different degree of openings were conducted in accordance with the following method.

- Selection of frame materials was conducted based on typical frame materials used in Indonesia, i.e. timber and Aluminum (Al). It was added by unplasticized Poly Vinyl Chloride (uPVC) frame as the latest frame material in buildings in Indonesia.

- The open window was selected with consideration of window types that may partially block outdoor noise. The most common window types are casement, top hung, and louver. A top hung window was selected since the shutter is positioned perpendicular to the sound source. It was predicted to be a good blockage.

- Glass type and opening dimension on the tested wall were determined as fixed variables. It based on earlier studies where thickness and dimension played important roles in the decrease or increase of OITC. Thicker glass owns higher OITC than thinner ones ${ }^{12}$. Larger glass dimension decreases OITC than smaller ones $^{12}$. A fixed glass thickness of $5 \mathrm{~mm}$ and an opening on the wall of $800 \mathrm{~mm} \times 1200 \mathrm{~mm}$ were determined (Fig.1,2,3).

- A testing method conforming to ASTM E90-0913 was employed here and a specific condition based on Annex. 3 , i.e. the use of a composite wall system was

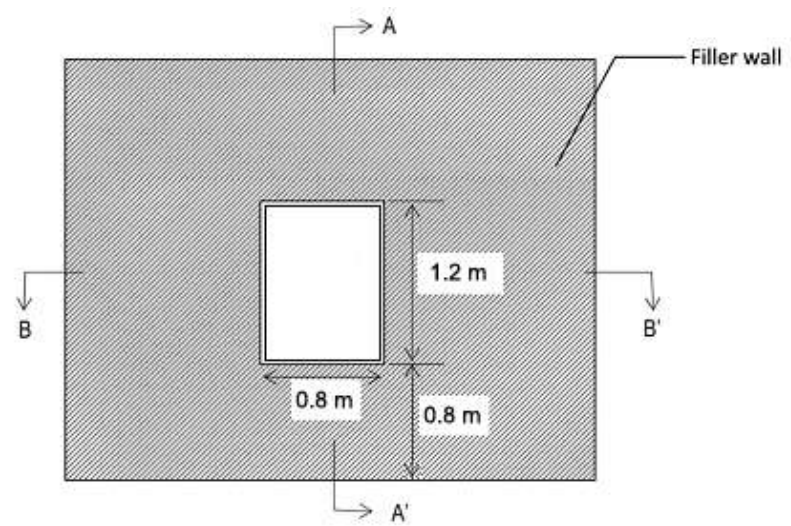

Fig 1. Front view of composite wall specimen. employed. This method corresponds to the typical window in Indonesia. It is mostly a combination of opaque and transparent walls. The opaque wall is constructed of lightweight bricks for multistory buildings or red bricks for domestic or single story buildings.

Reverberation chambers conforming to ASTM E90$09^{13}$ were utilized to conduct the test, with room layout as in Fig. 7 and 8. The temperature and relative humidity (RH) during the testing period were $25^{\circ}$ $26^{\circ} \mathrm{C}$ and $80 \%-90 \%$.

- In the composite wall system, a filler wall was developed. It was suggested to use filler wall with OITC of roughly 15 above the predicted OITC of the tested specimen. In this case, lightweight bricks plastered one side with a total thickness of $113 \mathrm{~mm}$ were used (Fig.1, and Fig. 2). The filler wall was tested prior to specimen installation, which gave STC 37 and OITC 34. For a reference, an open window gave STC $10^{14}$. This study used reference of STC due to unavailability of reference of OITC.

- Bruel \& Kjaer 2-channel building acoustics system consisting of power amplifier type 2734 and 4292 omnidirectional loudspeakers as sound sources, 2 pieces of type 4189 omnidirectional microphones as sound sensors, and 2-channel handheld analyzer type 2270 as the main instrument data processor were employed.The microphones were calibrated using type 4231 before the testing stage.

- At first, the test was conducted for fixed glass windows with three different frame materials, then for open top hung windows also with three different frame materials. The opening of the shutter was tested for three angles, i.e. $0^{\circ}$ (closed), $5^{\circ}$, and $10^{\circ}$. Ten degrees of an opening were considered as the maximum effective for top hung type so as not to obstruct corridor way and for safety reason.

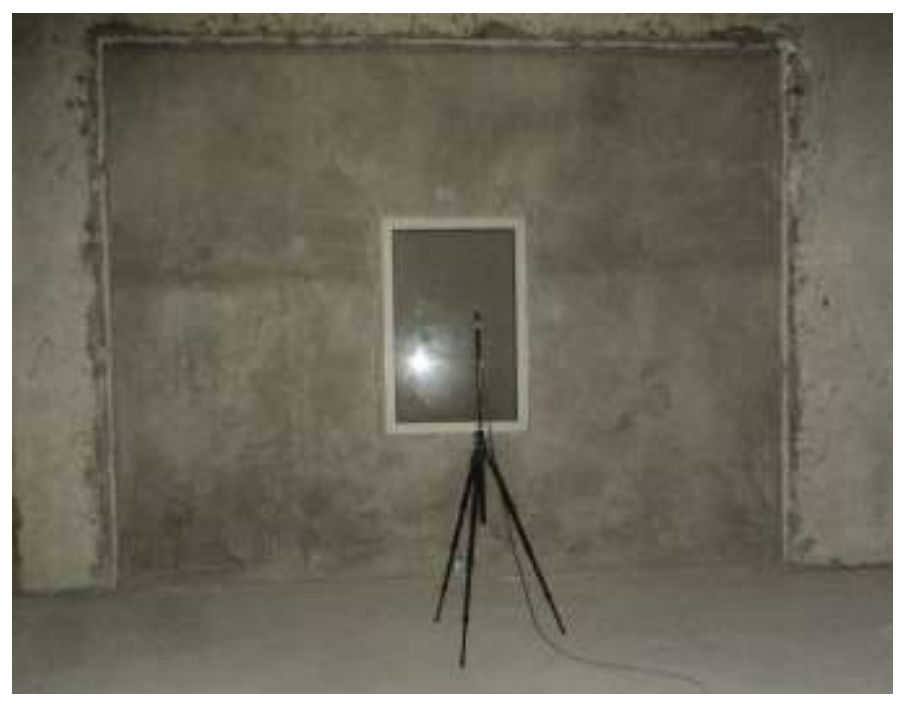

Fig. 2. Front view of composite wall specimen. 
Table.1. Specimen specification

\begin{tabular}{|c|c|c|c|}
\hline No. & $\begin{array}{l}\text { Frame } \\
\text { Material }\end{array}$ & Window specification & $\begin{array}{l}\text { Frame + } \\
\text { glass weight } \\
(\mathrm{kg})\end{array}$ \\
\hline 1 & $\begin{array}{l}\text { Timber } \\
\text { (Camphor } \\
\text { wood) }\end{array}$ & $\begin{array}{l}\text { The dimension including frame was } \\
800 \mathrm{~mm} \times 1200 \mathrm{~mm} \text {, the dimension of } \\
\text { frame only section was } 50 \mathrm{~mm} \times 100 \\
\mathrm{~mm} \text { (fixed window) and } 110 \mathrm{~mm} \times \\
100 \mathrm{~mm} \text { (open window), with Asahi's } \\
\text { monolithic glass of } 5 \mathrm{~mm} \text { thickness } \\
\text { (Fig. 4). }\end{array}$ & $\begin{array}{l}\text { Fixed } \\
\text { window } 21.5 \\
\text { Open window } \\
26.5\end{array}$ \\
\hline 2 & $\begin{array}{l}\text { Alumi- } \\
\text { num } \\
\text { (YKK } \\
\text { brand) }\end{array}$ & $\begin{array}{l}\text { The dimension including frame was } \\
800 \mathrm{~mm} \times 1200 \mathrm{~mm} \text {, the dimension of } \\
\text { frame only section was } 44.5 \mathrm{~mm} \times \\
101.6 \mathrm{~mm} \text { (fixed window) and } 74.5 \\
\text { mm x } 101.6 \mathrm{~mm} \text { (open window), with } \\
\text { Asahi's monolithic glass of } 5 \mathrm{~mm} \\
\text { thickness (Fig.5). }\end{array}$ & $\begin{array}{l}\text { Fixed } \\
\text { window } 10.5 \\
\text { Open window } \\
14.0\end{array}$ \\
\hline 3 & $\begin{array}{l}\text { uPVC } \\
\text { (Terry- } \\
\text { ham } \\
\text { Proplas } \\
\text { brand) }\end{array}$ & $\begin{array}{l}\text { The dimension including frame was } \\
800 \mathrm{~mm} \times 1200 \mathrm{~mm} \text {, the dimension of } \\
\text { frame only section was } 60 \mathrm{~mm} \times 60 \\
\mathrm{~mm} \text { (fixed window) and } 80 \mathrm{~mm} \times \\
950 \mathrm{~mm} \text { (open window), with Asahi's } \\
\text { monolithic glass of } 5 \mathrm{~mm} \text { thickness } \\
\text { (Fig. 6). }\end{array}$ & $\begin{array}{l}\text { Fixed } \\
\text { window } 14.5 \\
\text { Open window } \\
21.0\end{array}$ \\
\hline
\end{tabular}

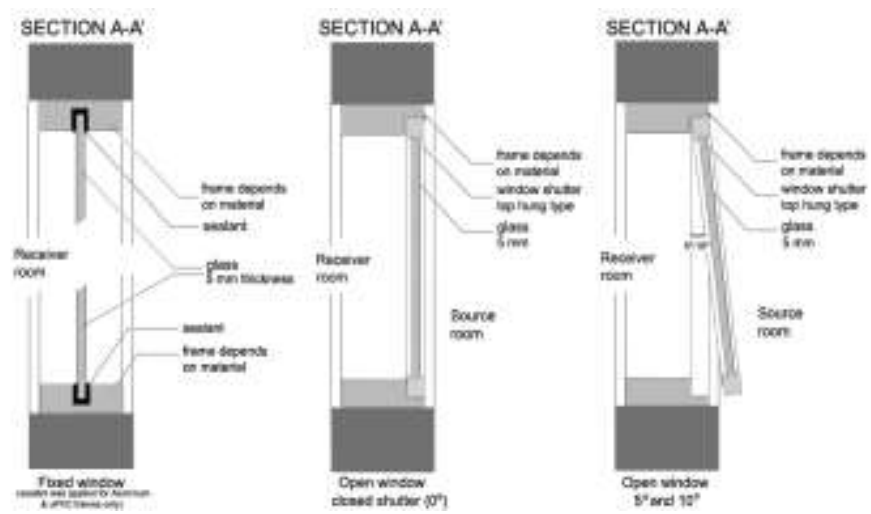

Fig 3. Schematic A-A' sections of the wall and the window. The details depend on whether fixed or open and frame materials.

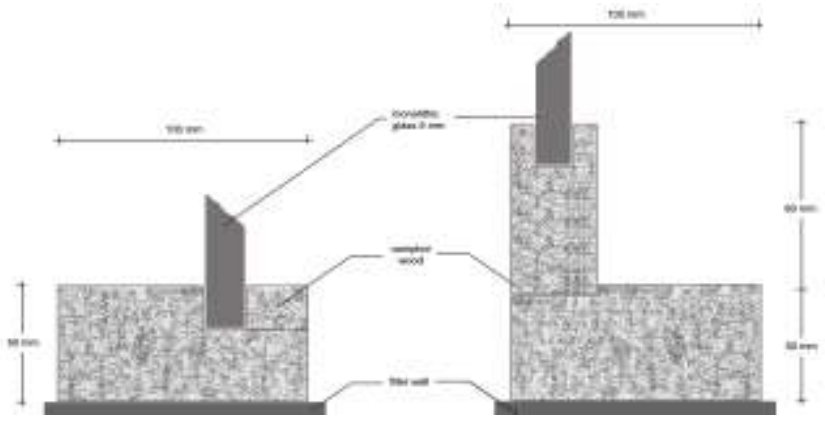

Fig. 4. Detailed section of the timber frame of fixed (left) and open (right).

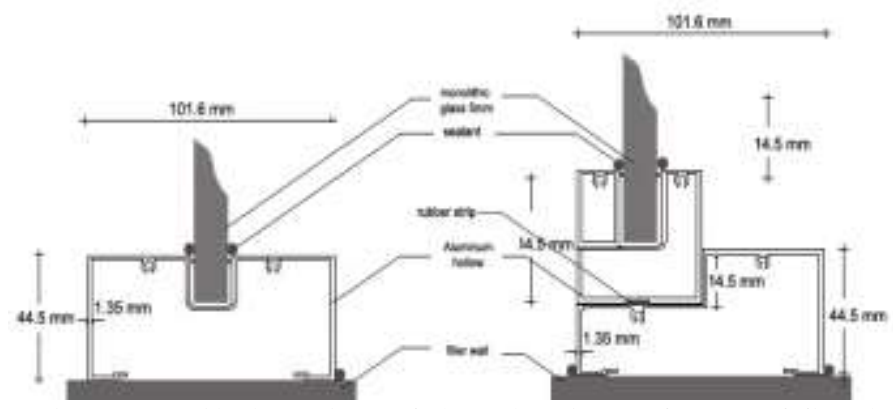

Fig.5. Detailed section of the Aluminum frame of fixed (left) and open (right).

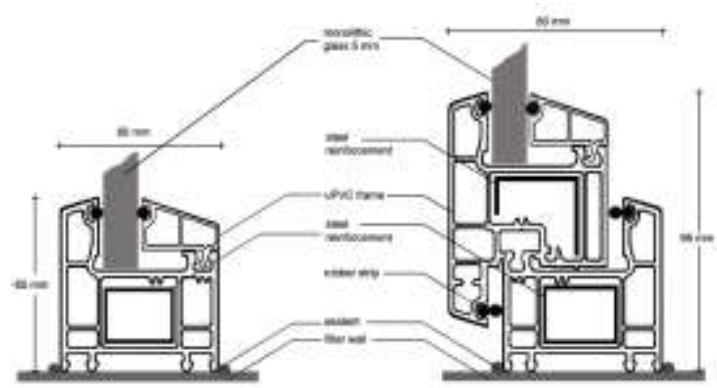

Fig.6. Detailed section of the uPVC frame of fixed (left) and open (right).

\section{FINDING AND DISCUSSION}

Earlier studies which suggested light materials or open features on wall dropped the sound insulation quality of the wall ${ }^{4-6}$ was strengthened in this study. Fig 9, 10 and Table 2 show that TL contour and OITC of fixed windows and open windows were significantly lower than the filler wall. Weight and density of material played significant roles in providing good sound insulation ${ }^{6}$. A heavy and high-density material gave better sound insulation $^{6}$. However, seemed it was not the case here. Camphor wood used in this study was heavier than the uPVC, but the TL contour and single number of OITC gave lower value than the uPVC. The camphor wood

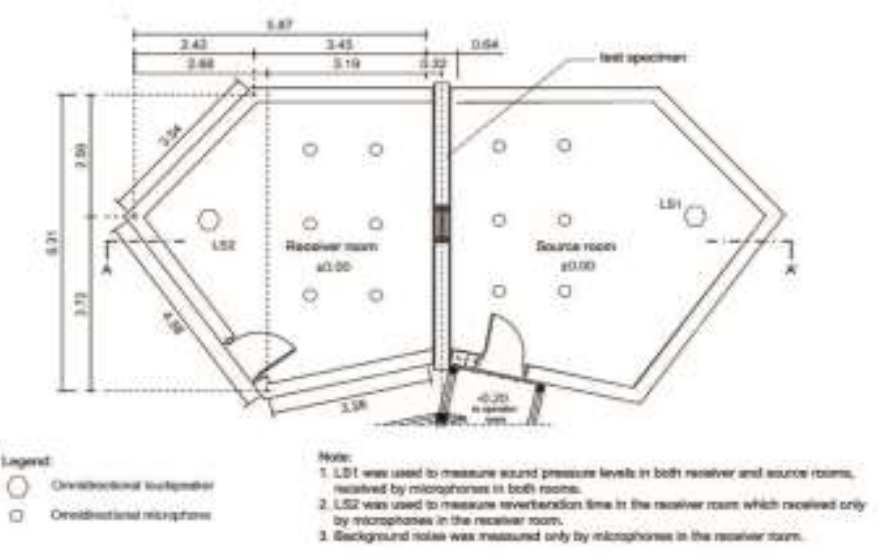

Fig 7. Plan of the testing rooms and the equipment layout.

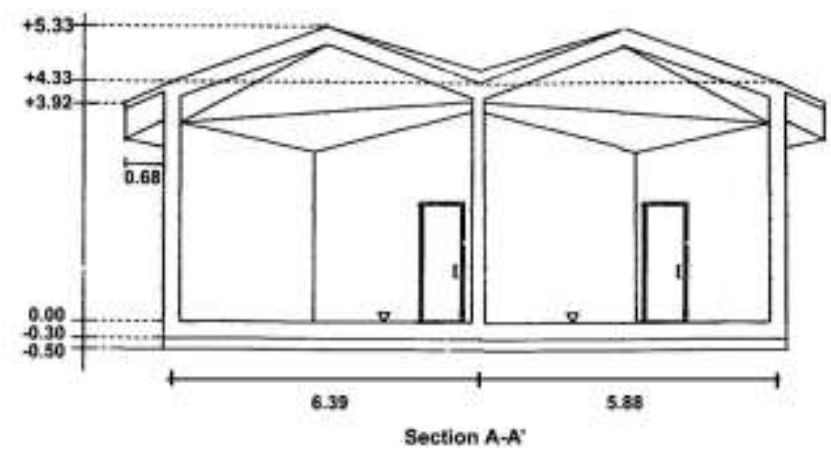

Fig 8. A-A' section of the testing rooms. 
frame gave even lower TL contour compared to the Aluminum frame which was very lightweight. Learning from Fig. 4, 5, and 6, we consider the low OITC and TL contour were due to the absence of sealant and rubber strips on the timber. By Fig. 6 in particular, we clearly notice the uPVC frame had many rubber strips and sealant. These two features were significant in blocking the sound pathways.

For an open timber window, the existence of a gap between layers reduced the material capability to insulate sound significantly, even when the openable window was closed (Fig. 9). The OITC and TL contour of the fixed timber window, even lower than the open window of $0^{\circ}$ (closed shutter) of Aluminum and uPVC frames.

When the open window was realy open with the degree of opening $5^{\circ}$ and $10^{\circ}$, the TL contour dropped even more significant. Fig. 10 and Table 2 show very low TL contours and very low OITC of the open windows of all frames. In general, the timber frame windows gave lowest TL contour and lowest OITC compared to the others within fixed and open $0^{\circ}$ types. In the timber frame windows, significant gaps were existed to accommodate thermal expansion. Also, for an open timber frame window, a wide gap between frame and shutter is typical for ease of use. A gap between materials did not exist when using Aluminum and uPVC. These materials have low coefficient of thermal expansions ${ }^{15}$ so the frame and the shutter can be installed very close each other. It was even better in uPVC as rubber strips are also attached between layers.

Table.2. Transmission Loss (dB) and OITC

\begin{tabular}{rccccccccccccc}
\hline Freq & $\mathbf{A}$ & $\mathbf{B}$ & $\mathbf{C}$ & $\mathbf{D}$ & $\mathbf{E}$ & $\mathbf{F}$ & $\mathbf{G}$ & $\mathbf{H}$ & $\mathbf{I}$ & $\mathbf{J}$ & $\mathbf{K}$ & $\mathbf{L}$ & $\mathbf{M}$ \\
\hline 80 & 41 & 28 & 29 & 33 & 24 & 31 & 31 & 18 & 21 & 19 & 15 & 15 & 18 \\
100 & 37 & 28 & 28 & 28 & 25 & 29 & 29 & 18 & 19 & 18 & 17 & 17 & 16 \\
125 & 31 & 19 & 20 & 19 & 15 & 21 & 21 & 10 & 11 & 9 & 9 & 9 & 9 \\
160 & 34 & 22 & 18 & 21 & 13 & 22 & 21 & 5 & 7 & 6 & 5 & 5 & 4 \\
200 & 29 & 19 & 19 & 20 & 16 & 19 & 20 & 6 & 7 & 7 & 4 & 4 & 4 \\
250 & 30 & 19 & 20 & 21 & 16 & 20 & 21 & 7 & 9 & 8 & 4 & 5 & 5 \\
315 & 29 & 20 & 21 & 22 & 17 & 21 & 22 & 7 & 8 & 9 & 4 & 6 & 6 \\
400 & 28 & 20 & 20 & 21 & 16 & 21 & 22 & 7 & 8 & 7 & 5 & 5 & 3 \\
500 & 32 & 22 & 23 & 23 & 18 & 23 & 23 & 6 & 7 & 6 & 4 & 4 & 3 \\
630 & 36 & 25 & 27 & 27 & 19 & 26 & 27 & 6 & 6 & 6 & 4 & 4 & 4 \\
800 & 38 & 27 & 28 & 29 & 20 & 28 & 29 & 6 & 6 & 5 & 5 & 4 & 4 \\
1000 & 41 & 28 & 30 & 31 & 20 & 29 & 31 & 6 & 6 & 5 & 5 & 5 & 4 \\
1250 & 44 & 27 & 31 & 33 & 21 & 32 & 34 & 6 & 6 & 6 & 6 & 5 & 4 \\
1600 & 47 & 28 & 31 & 35 & 22 & 33 & 35 & 7 & 6 & 6 & 6 & 4 & 4 \\
2000 & 49 & 27 & 29 & 32 & 22 & 31 & 33 & 7 & 6 & 6 & 6 & 4 & 5 \\
2500 & 51 & 23 & 26 & 29 & 19 & 28 & 31 & 7 & 7 & 8 & 6 & 5 & 6 \\
3150 & 53 & 22 & 22 & 27 & 16 & 26 & 31 & 8 & 8 & 10 & 6 & 6 & 7 \\
4000 & 55 & 25 & 26 & 29 & 15 & 27 & 33 & 8 & 9 & 11 & 6 & 6 & 6 \\
\hline OITC & $\mathbf{3 4}$ & $\mathbf{2 3}$ & $\mathbf{2 4}$ & $\mathbf{2 5}$ & $\mathbf{1 8}$ & $\mathbf{2 4}$ & $\mathbf{2 5}$ & $\mathbf{7}$ & $\mathbf{7}$ & $\mathbf{7}$ & $\mathbf{5}$ & $\mathbf{5}$ & $\mathbf{5}$ \\
\hline
\end{tabular}

* Legend of Table 2: A is the filler wall (lightweight bricks plastered toward source room with a total thickness $113 \mathrm{~mm}$ ), B is the fixed window with timber frame, $\mathrm{C}$ is the fixed window with Aluminum frame, D is the fixed window with uPVC frame, $\mathrm{E}$ is the open window with timber frame with closed shutter $\left(0^{\circ}\right), \mathrm{F}$ is the open window with Aluminum frame with closed shutter $\left(0^{\circ}\right), \mathrm{G}$ is the open window with uPVC frame with closed shutter $\left(0^{\circ}\right), \mathrm{H}$ is the $5^{\circ}$ open window with timber frame, $\mathrm{I}$ is the $5^{\circ}$ open window with Aluminum frame, $\mathrm{J}$ is the $5^{\circ}$ open window with uPVC frame, $\mathrm{K}$ is the $10^{\circ}$ open window with timber frame, $\mathrm{L}$ is the $10^{\circ}$ open window with Aluminum frame, and $\mathrm{M}$ is the $10^{\circ}$ open window with uPVC frame.

The OITCs were calculated from the TL of $1 / 3$ octave band frequency according to ASTM E1332-90 ${ }^{16}$.

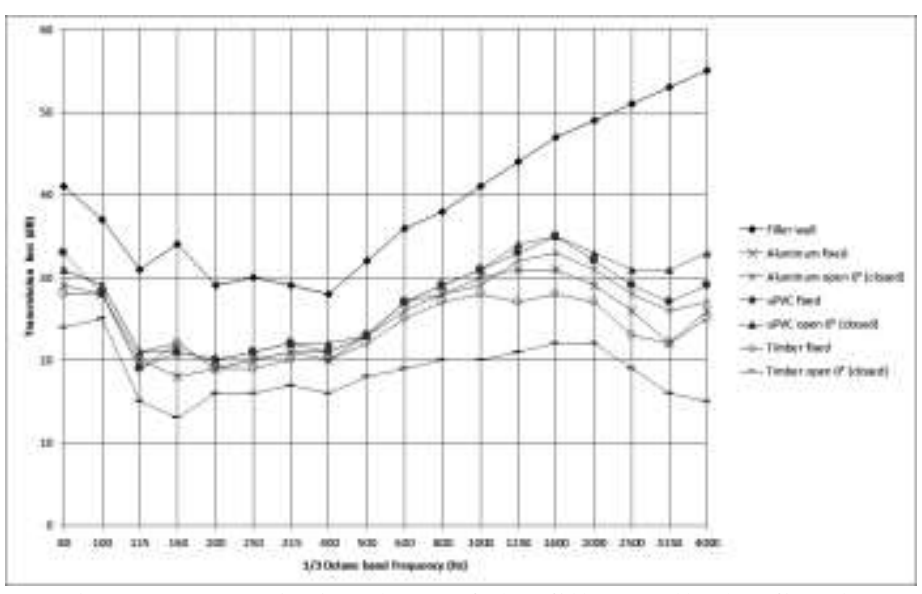

Fig. 9. Transmission loss of the filler wall, the fixed windows and the $0^{\circ}$ open windows (closed shutter).

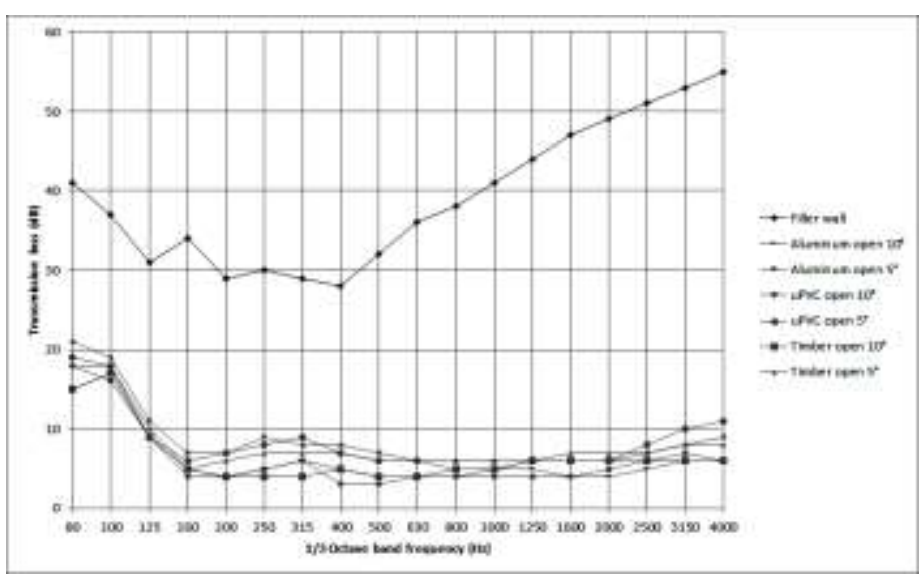

Fig. 10. Transmission loss of the filler wall and the $5^{\circ}$ and $10^{\circ}$ open windows.

\section{CONCLUSIONS}

This study concludes the timber frame used for fixed glass window gave similarly but slightly lower TL contour than the contour of Aluminum and uPVC. The similar contours mean the materials have similar critical frequencies. It also means the absence of sealant and rubber strips had a small impact on the TL contour and OITC here. Nevertheless, when the timber frame was installed for a top hung open window, even with closed shutter, the window gave a significantly lower TL contour and OITC. The TL contour and OITC of the fixed timber frame even lower than the open Aluminum and uPVC frames with closed shutters. Here, material weight did not play a role on sound insulation, all depended on the gaps filler which was sealant and rubber strips. The open top hung window with a smaller opening degree of $5^{\circ}$ gave slightly higher TL contour and OITC value than the $10^{\circ}$ opening.

\section{ACKNOWLEDGMENTS}

This study was fully funded by Ministry of Research, Technology and the Higher Education Republic of Indonesia under the scheme of Hibah Kompetensi under the project "Acoustical Characteristic of Architectural 
Glass in Warm Humid Climate" with contract number 023.04.1.673453/ 2015 (made through Kopertis Wilayah VII).

\section{REFERENCES}

[1] JD Quirt, Sound transmission through windows I single and double glazing. J. Acoust. Soc. Am 72 (1982) 834-844.

[2] JD Quirt, Measurement of the sound transmission loss of windows. Building Research Note 72 (1981) 1-7.

[3] Garg N, Sharma O and Maji S. Experimental investigations on sound insulation through single, double \& triple window glazing for traffic noise abatement. J Sci Ind Res 70 (2011) 471478Massart Thierry, Meuter Cedric, V B Laurent. On the complexity of partial order trace model checking, Inform. Process. Lett. 106 (2008) 120-126.

[4] CE Mediastika, L. Kristanto, J. Anggono, F.Suhedi and H. Purwaningsih, Sound transmission class (STC) of fixed window glazing in warm humid environment, Proc 7th International Conference on Environmental Science and Development (ICESD), Athens, 2015.

[5] CE Mediastika, L. Kristanto, J. Anggono, F.Suhedi and H. Purwaningsih, Building glass OITC in warm temperature, Procedia Engineering 145 (2016) 630-637.

[6] P. Lord and D. Templeton, Detailing for acoustic, Taylor Francis, (1996) 103.

[7] C.Buratti, Indoor noise reduction index with open window, Applied Acoustics 63 (2002) 383-401.

[8] C.Buratti, Indoor noise reduction index with an open window (part II), Applied Acoustics 6 (2006) 431-451.

[9] R. D. Ford and G. Kerry, The sound insulation of partially open double glazing, Applied Acoustics 6 (1973) 57-72.

[10] Mediastika, CE, Design solution for low-cost housing in hot humid regions with reference to particulate matter and noise reduction, 2000, Department of Architecture, University of Strathclyde, Glasgow, UK, unpublished Ph.D. dissertation.

[11] ----, The shrinkage and expansion of wood, available on http://www.wood-database.com/wood-articles/dimensionalshrinkage/ accessed on May 12 2016.

[12] -----, Sound investment how the acoustical properties of building products are measured and why this is important, available on http://www.jeld-wenresearch.com/_pdfs/Sound_Investment.pdf, accessed on Sep $28^{\text {th }}, 2015$.

[13] ASTM E90-09. Standard test method for laboratory measurement of airborne sound transmission loss of building partitions and elements. American Society for Testing and Materials, West Conshohocken, PA, 19428-2959 USA, 2009.

[14] R. McMullan, Environmental Science Handbook, London: MacMillan Press Ltd, 1992, p.202.

[15] ----, Coefficient of thermal expansion for various materials at different temperatures: technical report, Balseal Engineering, 2004, available on http://www.balseal.com/sites/default/files accesed on Sep $28^{\text {th }}, 2015$.

[16] ASTM E1332-90, Standard Classification for Determination of Outdoor-Indoor Transmission Class, American Society for Testing and Materials, West Conshohocken, PA, 19428-2959 USA, 1998, superseded by ASTM E1332-10a, Standard Classification for Rating OutdoorIndoor Sound Attenuation, American Society for Testing and Materials, West Conshohocken, PA, 19428-2959 USA, 2010. 